\title{
Oral Amphotericin B: The journey from bench to market
}

Dolores R. Serrano ${ }^{1,2}$ and Aikaterini Lalatsa ${ }^{3, *}$

${ }^{1}$ Departamento de Farmacia y Tecnología Farmacéutica, Facultad de Farmacia, Universidad Complutense de Madrid, Plaza Ramón y Cajal s/n, 28040-Madrid, Spain.

${ }^{2}$ Instituto Universitario de Farmacia Industrial (IUFI), School of Pharmacy, University Complutense, Avenida Complutense, 28040 Madrid, Spain.

${ }^{3}$ School of Pharmacy and Biomedical Sciences, University of Portsmouth, St. Michael's Building, White Swan Road, Portsmouth PO1 2DT, UK.

*Corresponding author

Dr. Aikaterini Lalatsa

School of Pharmacy and Biomedical Sciences

University of Portsmouth, St. Michael's Building

White Swan Road, Portsmouth PO1 2DT, UK.

Email: katerina.lalatsa@ port.ac.uk

Tel: 02392843929 


\begin{abstract}
Since the 1950s, amphotericin $\mathrm{B}(\mathrm{AmB})$ has been used in clinical practice to treat systemic fungal infections and leishmaniasis, a neglected parasitic disease that can be fatal if left untreated. Fungizone ${ }^{\circledR}$ (a micellar dispersion) was the "gold standard" for more than three decades but due to the safer profile of novel lipid-based medicines (AmBisome ${ }^{\circledR}$, Abelcet ${ }^{\circledR}$ and Amphocil $\AA$ ), it is now used as second-line in the developed world. Lipid-based medicines possess a more favourable safety profile (mainly lower nephrotoxicity and infusion-related side effects) allowing the administration of larger doses and therefore similar efficacy with fewer administrations. However, all formulations require parenteral administration because $\mathrm{AmB}$ has low oral bioavailability $(0.2-0.9 \%)$ due to the precipitation in aqueous media. In the last decade, strong partnerships between academia and industry has led to the development of innovative drug delivery systems able to deliver and target orally $\mathrm{AmB}$ in effective concentration while reducing its nephrotoxicity and infusion-related side effects. Currently, three major platform technologies (cochleates, chitosan nanoparticles and SEDDS) that are undergoing clinical trials that are discussed in this review. The pharmacokinetic and pharmacodynamic profile against visceral leishmaniasis, systemic candidiasis and aspergillosis of novel delivery systems will also be discussed.
\end{abstract}

Keywords: Amphotericin B, Ambisome ${ }^{\circledR}$, oral delivery, cochleates, self-emulsifying drug delivery systems (SEDDS), chitosan nanoparticles. 


\section{Introduction}

Since the 1950s, amphotericin B (AmB) is used in clinical practice to treat initially systemic fungal infections and several years later also leishmaniasis, a neglected parasitic disease that can be fatal when left untreated [1,2]. A micellar dispersion of AmB and sodium deoxycholate (Fungizone ${ }^{\circledR}$ ) was considered the "gold standard" for more than three decades due to its broad-spectrum activity and low incidence of clinical resistance in spite of causing severe adverse effects such as nephrotoxicity, anaemia and infusionrelated side effects [3]. However, Fungizone ${ }^{\circledR}$ was relegated to a second-line treatment in developed countries when lipid-based medicines $\left(\right.$ AmBisome $^{\circledR}$, Abelcet $^{\circledR}$ and Amphocil $^{\circledR}$ ) were marketed in the 1990s. Lipidic formulations exhibit similar efficacies but more favourable safety profiles (mainly lower nephrotoxicity) which allows the intravenous administration of higher doses $(5-10 \mathrm{mg} / \mathrm{kg}$ compared to the $0.5-1 \mathrm{mg} / \mathrm{kg}$ recommended dose for Fungizone ${ }^{\circledR}$ ) $[4,5]$. Infusion-related side effects and the need for patient hospitalization to monitor for $\mathrm{AmB}$ side effects remain still an issue for lipidic formulations and limits the access to $\mathrm{AmB}$ treatment in developing countries. An oral self-administered AmB formulation can overcome these challenges, however, this has not yet been materialized.

\section{Why has an oral AmB medicine not been marketed till now?}

In clinical practice, $\mathrm{AmB}$ is administered orally only when a local action is desired, for example to prevent nosocomial infections in the oesophageal and gastrointestinal tract [6]. The main reason of requiring IV administration is the low fraction of $\mathrm{AmB}$ that is orally absorbed (0.2-0.9\%) due to the precipitation of crystalline drug in aqueous media (Figure 1a) [6, 7]. The zwitterionic and amphiphilic character of AmB with an asymmetrical distribution of ionisable carboxyl and primary amine groups and hydrophobic and hydrophilic groups respectively leads to poor aqueous solubility $(<1$ $\mathrm{mg} \mathrm{L}^{-1}$ at physiological $\left.\mathrm{pH}\right)[7,8]$. AmB violates Lipinski's rule of five possessing a molecular weight of $924 \mathrm{Da}, 12 \mathrm{H}$-bond donors and $18 \mathrm{H}$-bond acceptors [3, 9]. Thus, to achieve clinical effective $\mathrm{AmB}$ concentrations in targeted organs after the oral administration, chemical modification of the drug or reformulation using appropriate excipients is required. The latter will require excipients able to increase AmB's aqueous solubility $[10,11]$ as well as ensure stability of the drug throughout all the harsh environment of the gastrointestinal tract (GIT) such as the low $\mathrm{pH}$ of the stomach and 
facilitate the drug absorption through the enterocytes (reaching the portal blood) or Mcells (till the lymphatic route).

\section{Pharmacokinetics of oral AmB}

AmB was originally orally studied for its pharmacokinetics in humans in 1957 even at very high doses of 2-10 g daily (Table 1) [12-14]. Two decades later [6], lower doses of AmB were orally administered (30-40 mg/day) for infections of the GIT. Interestingly both high doses and lower doses resulted in similar plasma concentrations (Table 1). Researchers speculated that the absorption process may be saturated (reaching a maximum plateau) after oral administration and thus, multiple administrations of lower doses could results in higher plasma levels than a single high dose of AmB.

Advancements in drug delivery technologies and the emergence of nano-enabled formulations have enhanced research efforts of academic and industrial researchers in the last two decades. Various delivery strategies including polymeric and solid lipid nanoparticles [15-17], micellar dispersions [18], cochleates [19], nanosuspensions [20], carbonanotubes [21] and lipid-based nanomedicines [22-24] have been reported with varying degrees of success in achieving effective plasma and tissue after oral administration and moving further in human clinical trials (Table 2-6).

Single dose pharmacokinetics studies in animals have illustrated that tissue-plasma ratio is a key factor to take into account after oral administration of AmB (Table 2). A low plasma concentration does not necessarily indicate that the formulation is ineffective. Due to its physicochemical properties, $\mathrm{AmB}$ accumulates in tissues for longer periods of time leading to long half-life after intravenous administration [25]. Tissue accumulation is similarly observed after oral administration. For this reason, determination of AmB levels in organs of interest such as liver and spleen for visceral leishmaniasis and lungs, kidneys, brain and liver for fungal infections is critical in the evaluation of an $\mathrm{AmB}$ oral candidate formulation. Bearing in mind the in vitro effective concentrations of $\mathrm{AmB}$ against fungal and parasitic strains (reported $\mathrm{IC}_{50}$ between 0.1 to $2 \mu \mathrm{g} / \mathrm{ml}$ [26-28]), levels reached in tissues of interest equal or higher to the in vitro $\mathrm{IC}_{50}$ after oral administration could be effective.

After evaluating the published data on single oral administration of $\mathrm{AmB}$ in rodents, several conclusions can be drawn (Table 2). Saturated absorption impacts on the overall 
oral bioavailability and AmB follows a non-linear pharmacokinetic profile. No significant higher levels were achieved when a dose of $50 \mathrm{mg} / \mathrm{kg}$ of Peceol-AmB was administered compared to $5 \mathrm{mg} / \mathrm{kg}[18,24,29]$. P-glycoprotein ATPase activity may be involved in the saturation process. However, Osei-Twum et al. have shown that AmB was not a substrate of P-glycoprotein mediated efflux [30]. Lipid-based formulations appear to have a later Tmax (between 2-12.5 hours) and the Tmax increases with increasing dose. Lymphatic absorption can contribute to the later Tmax. Doses below $5 \mathrm{mg} \mathrm{kg}^{-1}$ fail to produce plasma levels above $0.1 \mu \mathrm{g} \mathrm{mL}-1$ which are required in vitro to elicit an effect. The situation is more complicated for polymeric nanoparticles. Polylactic-co-glycolic acid (PLGA, 50:50) nanoparticles have illustrated a sustained response, while chitosan based nanoparticles illustrated an early onset Tmax and greater plasma concentrations (Table 2). Single dose pharmacokinetic levels in both plasma and tissues are critical for designing a multiple dose regime that can prove to be more efficacious exploiting the accumulation of $\mathrm{AmB}$ in the body and its high tissue distribution. The gastrointestinal toxicity of AmB, which manifests as mild nausea, vomiting, diarrhea and loss of appetite, remains a major limitation for oral strategies taking into account the higher oral AmB dose administered needed for ensuring oral bioavailability and tissue accumulation. A high oral dose combined with non-linear and variable pharmacokinetics might result in acute nephrotoxicity and this needs to be taken into account in multiple dose regimes.

Multiple doses have been reported for lipid-based and polymeric formulations with doses ranging between 2.5-20 mg kg-1 twice daily. Similarly, a dose above $5 \mathrm{mg} \mathrm{kg}^{-1}$ elicited adequate plasma concentrations and an equivalent or higher $\mathrm{AmB}$ concentration in liver compared to kidney. However, in visceral leishmaniasis (VL) infected animals, a lower accumulation in liver has been reported compared to non-infected animals after intravenous administration of Ambisome $\left(2 \mathrm{mg} \mathrm{kg}^{-1}\right)$ or lipid-based nanoemulsions orally (10-20 mg kg-1 twice daily for 5 days). Researchers have speculated that the liver and spleen macrophages of VL infected mice lose their phagocytic activity [24]. Macrophages infected with $L$. donovani in vitro illustrate a lower phagocytic activity compared to uninfected cells [31].

The most successful formulations able to deliver greater amounts of drug in tissues in rodent model were cochleates [19], lipid-based systems [22, 29] and polymeric nanoparticles [15]. From all the formulations, AmB-GCPQ (N-palmitoyl-N-methyl-N,Ndimethyl-N,N,N-trimethyl-6-O-glycol chitosan) nanoparticles showed oral 
bioavailability not only in rodents but also in dogs and possesses one major differential characteristic compared the other formulations: preferential drug accumulation in liver, spleen and lung leading to highest spleen/kidney and high liver/kidney and lung/kidney ratios. Cochleates were the only formulation to show almost four fold accumulation in the lungs compared to the liver and kidneys [19].

\section{Pharmacodynamics of oral AmB}

AmB activity after oral administration has been mostly tested against VL, systemic candidiasis and aspergillosis (Tables 4-6) but also research against other parasitic diseases such as trypanosomiasis is recently published [32].

The size of particulate formulations is a key characteristic for ensuring adequate targeting of AmB strategies in murine VL models to reach reticuloendothelial (RES) organs (Table 4). Poor activity levels were achieved after the oral administration of a nanosuspension consisting of polysorbate 80, pluronic F68 and sodium cholate with a particle size greater than $500 \mathrm{~nm}$ [20]. However, greater parasitaemia reduction in liver and spleen was obtained with: i) $\mathrm{AmB}$ attached to functionalized carbon nanotubes (long axial, width approximately $50 \mathrm{~nm}$ ) [21], ii) lipid-based emulsions such as iCo-10 (approximately 200 $\mathrm{nm})$ composed of 60/40 (v/v) mono- and diglycerides (Peceol/Gelucire 44/14) with vitamin E-TPGS (D- $\alpha$-tocopheryl polyethylene glycol succinate) [33, 34] and iii) polymeric AmB-GCPQ nanoparticles with similar particle size (approximately $200 \mathrm{~nm}$ ) [15]. Therapeutic regimes of $2.5 \mathrm{mg} / \mathrm{kg}$ twice daily were insufficient to eradicate the parasitemia while doses equal or above $5 \mathrm{mg} / \mathrm{kg}$ once or twice daily for at least 5 consecutive days were able to deliver enough $\mathrm{AmB}$ to elicit its pharmacological effect. Leishmania is an intracellular parasite accumulated in the RES organs (liver, spleen, bone marrow) and targeting these organs will lead to a better therapeutic outcome. The oral route is ideal for liver targeting as the drug reaches the liver via the portal blood circulation after absorption, while lymphatic uptake can enable bone marrow targeting.

A complication in comparing the efficacy of oral $\mathrm{AmB}$ formulations in apergillos is is the use of different infection models (Table 5), which use different number of colonies to induce the infection that impacts in treating animals of varying degrees of neutropenia with tested formulations and does not allow direct comparison of the strategies and doses used. Compared to parasitic infections like VL, fungal apergillosis caused by A.fumigatus is more severe and higher doses (> 15-20 mg kg-1) and longer duration of therapy (>10 
days) are necessary to prolong the survival rate and inhibit the growth of Aspergillus in infected tissues. Also, the infection is more disseminated, thus, higher levels of AmB are required not only in liver and spleen but also in plasma, lungs, kidneys and brain. Oral AmB strategies for aspergillosis involved lipid based systems [35, 36], polymeric nanoparticles [15, 17] and cochleates [37], with the latter being the most successful formulation in preclinical studies. The same formulations were also tested in a systemic candidiasis animal model and treatment for longer periods of time was more efficacio us at eradicating the $C$. albicans from the infected tissues after oral $\mathrm{AmB}$ administration (Table 6) and are the ones closer to translating into an oral AmB formulation.

\section{A step closer to oral AmB}

Engineering oral $\mathrm{AmB}$ drug delivery systems requires: i) an increased $\mathrm{AmB}$ dissolution in the gastrointestinal tract, (ii) enhancement of lymphatic absorption, (iii) reduction in drug degradation in the acidic $\mathrm{pH}$ of the stomach, (iv) enhancement of the gastrointestinal transit and (v) finally targeting of the formulation in organs of interest and reducing offtarget side-effects (e.g. nephrotoxicity). The three most promising delivery strategies that have entered clinical trials are described in more detail below:

\section{CAmB- Amphotericin B cochlehates (Aquarious Biotechnologies- Matinas}

Biopharma) [38]. Clinical trials phase Ihave been completed and currently, the company is recruiting participants to initiate a Phase II clinical trial [39]. This platform technology is based on the encapsulation of $\mathrm{AmB}$ within cochleates which are stable cationic phospholipid precipitates composed of commonly used excipients such as phosphatidylserine and calcium. They have a multilayer structure consisting of a large, continuous, solid lipid bilayer sheet rolled up in a spiral without aqueous space (Figure 1b) [40]. The structure of the cochleates provides protection from the acidic gastric $\mathrm{pH}$ because the entire cochleate structure is composed of a series of solid layers and even though the outer layers can be exposed to harsh environmental conditions, the interior of the cochleate remains intact. $\mathrm{AmB}$ cochleates have shown comparable efficacy in vivo to parenteral liposomal AmBisome ${ }^{\circledR}$ in three disease states (VL, candidiasis and aspergillosis) [37, 40-42]. However, the scaling-up process can be complex as one of the major limitations is that the cochleate structure is not always uniform resulting in either aggregates or stacked sheets and cochleates or large size needles-like structures [43]. 
2. NM0147 METAmphizon (Nanomerics) [44]. AmB nanoparticles are obtained using Molecular Envelope Technology (MET) and engineered from a biocompatible polymer. AmB is encapsulated within N-palmitoyl-N-methyl N,N-dimethyl-N,N,N-trimethyl-6-Oglycol chitosan (GCPQ) nanoparticles of about $200 \mathrm{~nm}$ in size [15]. The particles have a core-shell structure with the ionic units forming the particle shells and the hydrophobic groups forming the particle core (Figure 1c). The hydrophobic tail of the polymer has the same number of carbons as the hydrophobic domain of $\mathrm{AmB}$, which enhances the hydrophobic interaction and the formation of a nanocomplex [15]. The oral bioavailability of AmB-GCPQ nanoparticles is $24 \%$ and similar to AmB cochleates, AmB encapsulated in GCPQ nanoparticles also has shown a high efficacy against candidias is, aspergillosis and VL compared to parenteral administered AmBisome ${ }^{\circledR}$ [15]. Currently, METAmphizon is in clinical trials Phase I and preclinical studies have shown ability to: protect $\mathrm{AmB}$ from gastric degradation, reduce nephrotoxicity and enhance lymphatic absorption while target to lung, liver and spleen. The lower accumulation in the kidneys is favourable as the nephrotoxicity is reduced but at the same time, it can be a limitation in those cases where the microorganisms are localised in the kidneys.

3. iCo-Amphotericin B (iCo Therapeutics Inc) [45]. iCo Therapeutics has developed self-emulsifying drug delivery systems (SEDDS) to enhance oral AmB bioavailability which are currently in Phase I. There are two main formulations in their pipeline: iCo009 and iCo-010. The iCo-009 system is composed of AmB mixed with Peceol ${ }^{\circledR}$ (glyceryl monooleate) and distearoylphosphatidylethanolamine (DSPE)-(PEG)2000 and is characterised by excellent homogeneity and no crystalline features [35]. Accumulation of $\mathrm{AmB}$ in liver, spleen, kidney and lung tissues was reached after the oral administration of the formulation without inducing gastrointestinal toxicity leading to high efficacy against candidiasis, aspergillosis and leishmaniasis [22]. The iCo-010 system is a novel oral AmB formulation consisting of $\mathrm{Peceol}^{\circledR}$, Gelucire ${ }^{\circledR}$ 44/14 (lauroyl macrogol-32glycerides) and vitamin E-TPGS that remains highly effective against murine systemic candidiasis following exposure to tropical temperatures $\left(43^{\circ} \mathrm{C}\right)$. This is advantageous bearing in mind that neglected diseases occur mainly in tropical regions and $\mathrm{AmB}$ is a thermally unstable drug [46]. However, one of the limitations of this system is the low level of AmB solubilized in the aqueous fraction $(<20 \%)$ during lipolysis studies which is indicative of the amount of the drug that is available for absorption [47]. 
Oral administration can enable liver targeting as $\mathrm{AmB}$ will be transported to the liver, an important site of replication of the leishmania parasite, via the portal circulation. Oral administration of particulate formulations $(<300 \mathrm{~nm})$ can target $M$ cells and result in lymphatic uptake and has been shown to play a key role in the oral bioavailability of both AmB-GCPQ nanoparticles and SEDDS [15, 48]. Khan et al. have suggested that a particle size of $100-500 \mathrm{~nm}$ is optimal for lymphatic uptake via the GI lymphatic system $[49,50]$. Apart from particle size, the particle composition is critical. Chitosan polymers have been shown to adsorb great amounts of bile salts [51] during their transit through the GIT which can facilitate enterohepatic recirculation and enable their incorporation into chylomicrons and entrance in the lymphatic vessels, a process similar to what has been described for lipid-based SEDDS [52]. Bearing in mind that the Leishmania parasites reside in lymph nodes and they accumulate in RES tissues, the lymphatic uptake of AmB facilitates accumulation of the drug in tissues of interest enabling efficacious treatment of this parasitic disease [53].

\section{Translating oral nanomedicines of AmB: cost-effectiveness}

Even though the number of doses needed will be higher in the oral regime compared to a single IV administration of the drug to obtain the same level of efficacy, the overall cost of treatment may be lower taking into account both direct and indirect costs. Parenteral administration requires patient hospitalization and drug monitoring due to the acute and sometimes fatal infusion-related adverse effects such as anaphylactic reactions and nephrotoxicity which prolongs hospitalization. Parenteral formulations need to be sterile, while oral formulations such as the SEDDS or polymeric nanoparticles are cheaper to procude under GMP conditions and are easily scalable compared to liposomes $\left(\right.$ AmBisome ${ }^{\circledR}$ ). Oral AmB permit self-administration and can be distributed in rural areas and results in fewer adverse effects. Moreover, oral AmB formulations have been shown to be stable at tropical conditions not requiring a cold transport chain and cold storage reducing further the final cost of the oral formulations.

Clinical translation of oral AmB has been only evaluated in VL and not in other clinical manifestations of leishmaniasis such as mucocutaneous (MCL) and diffuse cutaneous (DCL) forms alone or in combination with topical treatments.

\section{Future perspectives and concluding remarks}


Several years before an oral AmB would be unthinkable. Higher doses and longer duration of treatment than those used parenterally are required to eradicate the microorganisms from affected tissues. Further toxicological studies in humans upon longer administration periods are required to assess the risk-benefit ratio. However, in the last decade, strong partnerships between academia and industry has led to the development of innovative drug delivery systems able to deliver oral AmB in enough concentration in targeted tissues to elicit its pharmacological effect while reducing its nephrotoxicity and infusion-related side effects. Currently, the road to market for oral $\mathrm{AmB}$ medicines is paved by three major platform technologies (cochleates, chitosan nanoparticles and SEDDS) undergoing clinical trials. Apart from the toxicity, other major limitations of these systems that have to be carefully taken into consideration are the scaling- up of the fabrication as well as the polymer synthesis and GMP production in order to get overall cost-effective formulations allowing the access of oral AmB treatment worldwide especially in developing countries.

\section{Acknowledgements}

This work was financially supported by the Sir Halley Stewart Trust (127) small grant to Dr Aikaterini Lalatsa.

\section{Figure captions:}

Figure 1. AmB electron micrographs: A) TEM of Crystals of AmB in dextrose 5\% (w/v) (reprinted with permission from [15]. Copyright (2015) American Chemical Society); B) Electron micrograph freeze-fracture of cochleates [54]; c) TEM of AmB- GCPQ nanoparticles in deionised water (reprinted with permission from [15]. Copyright (2015) American Chemical Society). 
Table 1: Oral pharmacokinetics studies in humans with AmB. Key: - data non available.

\begin{tabular}{|c|c|c|c|c|c|c|}
\hline Formulation & $\begin{array}{c}\text { Number of } \\
\text { patients }\end{array}$ & $\begin{array}{l}\text { Tretment } \\
\text { (duration) }\end{array}$ & Regime & Sampling & $\begin{array}{c}\text { Cmax plasma } \\
(\mu \mathrm{g} / \mathrm{ml})\end{array}$ & Ref. \\
\hline \multirow{3}{*}{$\mathrm{AmB}$} & 5 & $2 \mathrm{~g} / \mathrm{day}$ & Single dose & \multirow{3}{*}{-} & 0.040 & \multirow{3}{*}[12]{} \\
\hline & 5 & $4 \mathrm{~g} /$ day (1 day) & Multiple & & 0.080 & \\
\hline & 5 & $10 \mathrm{~g} /$ day (3 days) & Multiple & & 0.210 & \\
\hline $\mathrm{AmB}$ & 15 & $4.2 \mathrm{~g} /$ day (2 days) & Multiple & - & 0.180 & [14] \\
\hline $\begin{array}{c}\text { Solubilised } \\
\text { AmB }\end{array}$ & 9 & $\begin{array}{l}5.8 \mathrm{~g} / \text { day } \\
(10 \text { days })\end{array}$ & Multiple & - & 0.054 & [13] \\
\hline \multirow{2}{*}{$\begin{array}{l}\text { Tablet AmB } \\
10 \mathrm{mg} \\
\text { (Fungilin }^{\circledR} \text { ) }\end{array}$} & 3 & $30 \mathrm{mg} /$ day (2 days) & Multiple & $\begin{array}{l}3 \mathrm{~h} \text { after dose in } \\
\text { the morning }\end{array}$ & 0.068 & \multirow{2}{*}{ [6] } \\
\hline & 2 & $40 \mathrm{mg} /$ day (2 days) & Multiple & $\begin{array}{l}3 \mathrm{~h} \text { after dose in } \\
\text { the morning }\end{array}$ & 0.068 & \\
\hline
\end{tabular}


Table 2: Single dose oral pharmacokinetics animal studies with AmB. Key: -, data no available; ND, no detectable, below limit of quantification; D-AmB, Sodium deoxycholate - Amphotericin B; Albelcet, AmB-lipid complex suspension; Intralipid-AmB, AmB incorporated into 10\% intralipid; Peceol-AmB, AmB incorporated in 100\% Peceol (Self-emulsifying drug delivery system formulation: SEDDS); PLGA: polylactic-co-glycolic Acid (50:50), DSPE/PEG2000 (iCo-009), distearoylphosphatidiylethanolamine-poly-(ethylene glycol)2000; iCo 010, 60/40 (v/v) mono- and diglycerides with vitamin E-TPGS (D- $\alpha$-tocopheryl polyethylene glycol succinate); AmB-cochleates* data are extrapolated from the graph pub. No: US 2003/0228355 A1 patent; SLN, solid lipid nanoparticles; GCPQ- N-palmitoyl-N-methyl-N, Ndimethyl-N,N,N-trimethyl-6-O-glycol chitosan

\begin{tabular}{|c|c|c|c|c|c|c|c|c|c|c|c|c|}
\hline \multirow{2}{*}{ Formulation } & \multirow{2}{*}{$\begin{array}{l}\text { Animal model } \\
\left(\mathrm{n}^{0} \text { animals }\right)\end{array}$} & \multirow{2}{*}{ Therapy } & \multirow{2}{*}{$\begin{array}{c}\text { Collection of the } \\
\text { samples }\end{array}$} & \multirow{2}{*}{$\begin{array}{c}\text { T max } \\
\text { plasma } \\
\text { (h) }\end{array}$} & \multirow{2}{*}{$\begin{array}{c}\text { Cmax } \\
\text { plasma } \\
(\mu \mathrm{g} / \mathrm{mL})\end{array}$} & \multicolumn{6}{|c|}{ AmB concentration in tissues $(\mu \mathrm{g} \mathrm{AmB} / \mathrm{g}$ tissue $)$} & \multirow{2}{*}{ Ref. } \\
\hline & & & & & & Liver & Spleen & Kidney & Lung & Brain & Heart & \\
\hline D-AmB & Rat $(n=10)$ & $\begin{array}{c}1.6-16.7 \\
\mathrm{mg} / \mathrm{kg}\end{array}$ & - & $5-9$ & $\begin{array}{c}0.040- \\
0.100 \\
\end{array}$ & - & - & - & - & - & - & {$[55]$} \\
\hline \multirow{2}{*}{$\begin{array}{c}\text { D-AmB } \\
\left(\text { Fungizone }^{\circledR}\right)\end{array}$} & Rat $(n=6)$ & $5 \mathrm{mg} / \mathrm{kg}$ & \multirow{6}{*}{$\begin{array}{l}24 \mathrm{~h} \text { post- } \\
\text { administration }\end{array}$} & ND & ND & ND & ND & ND & ND & - & ND & \multirow{6}{*}[18]{} \\
\hline & Rat $(n=6)$ & $50 \mathrm{mg} / \mathrm{kg}$ & & 8 & 0.0398 & ND & ND & 0.009 & 0.731 & - & ND & \\
\hline Albelcet $^{\circledR}$ & Rat $(n=6)$ & $50 \mathrm{mg} / \mathrm{kg}$ & & 10 & 0.0485 & ND & ND & ND & 0.558 & - & 0.0459 & \\
\hline Intralipid-AmB & Rat $(n=6)$ & $50 \mathrm{mg} / \mathrm{kg}$ & & 2 & 0.719 & 0.0134 & ND & ND & 43 & - & ND & \\
\hline Peceol-AmB & Rat $(n=6)$ & $5 \mathrm{mg} / \mathrm{kg}$ & & 2 & 1.187 & 0.0061 & ND & ND & ND & - & ND & \\
\hline Peceol-AmB & Rat $(n=6)$ & $50 \mathrm{mg} / \mathrm{kg}$ & & 4 & 1.469 & 0.0109 & 0.0765 & ND & ND & - & 0.0128 & \\
\hline $\begin{array}{c}\text { AmB PLGA } \\
\text { nanopartícles }\end{array}$ & Rat $(n=3)$ & $10 \mathrm{mg} / \mathrm{kg}$ & \multirow[b]{2}{*}{-} & 24 & 0.176 & \multirow[b]{2}{*}{-} & \multirow[b]{2}{*}{ - } & \multirow[b]{2}{*}{-} & \multirow[b]{2}{*}{ - } & \multirow[b]{2}{*}{ - } & \multirow[b]{2}{*}{ - } & \multirow{2}{*}[56]{} \\
\hline $\begin{array}{c}\text { D-AmB } \\
\left.\text { (Fungizone }^{\circledR}\right) \\
\end{array}$ & Rat $(n=3)$ & $10 \mathrm{mg} / \mathrm{kg}$ & & 6 & 0.0602 & & & & & & & \\
\hline \multirow{2}{*}{$\begin{array}{c}\text { Peceol/DSPE/ } \\
\text { PEG } 2000^{-} \text {AmB }\end{array}$} & Rat $(n=6)$ & $4.5 \mathrm{mg} / \mathrm{kg}$ & \multirow{2}{*}{$\begin{array}{c}72 \text { h post- } \\
\text { administration }\end{array}$} & 6.3 & 0.071 & 0.017 & 0.091 & 0.079 & 0.117 & ND & ND & \multirow{2}{*}{ [23] } \\
\hline & Rat $(n=8)$ & $10 \mathrm{mg} / \mathrm{kg}$ & & 12.5 & 0.096 & 0.033 & 0.039 & 0.283 & 0.055 & ND & ND & \\
\hline AmbiOnp (SLN) & Rat $(n=4)$ & $200 \mathrm{mg} / \mathrm{kg}$ & \multirow{2}{*}{-} & 9 & 0.124 & - & - & - & - & - & - & \multirow[b]{2}{*}[16]{} \\
\hline $\begin{array}{c}\text { AmB dissolved in } \\
\text { DMSO }\end{array}$ & Rat $(n=4)$ & $200 \mathrm{mg} / \mathrm{kg}$ & & 12 & 0.142 & - & - & - & - & - & - & \\
\hline \multirow{3}{*}{ AmB-Cochleates* } & $\begin{array}{c}\text { Mice C57BL16 } \\
(\mathrm{n}=3)\end{array}$ & $10 \mathrm{mg} / \mathrm{kg}$ & $\begin{array}{c}1 \mathrm{~h} \text { post- } \\
\text { administration }\end{array}$ & - & - & 0.04 & ND & 0.04 & 0.04 & 0.02 & 0.04 & \multirow{3}{*}{ [19] } \\
\hline & $\begin{array}{l}\text { Mice C57BL16 } \\
(\mathrm{n}=3)\end{array}$ & $10 \mathrm{mg} / \mathrm{kg}$ & $\begin{array}{c}6 \mathrm{~h} \text { post- } \\
\text { administrationn }\end{array}$ & - & - & 0.72 & 0.6 & 0.96 & 0.96 & 0.48 & 0.1 & \\
\hline & $\begin{array}{c}\begin{array}{c}\text { Mice C57BL16 } \\
(\mathrm{n}=3)\end{array} \\
\end{array}$ & $10 \mathrm{mg} / \mathrm{kg}$ & $\begin{array}{c}24 \mathrm{~h} \text { post- } \\
\text { administrationn } \\
\end{array}$ & - & - & 0.4 & 0.36 & 0.16 & 0.22 & ND & ND & \\
\hline \multirow{2}{*}{$\begin{array}{c}\text { AmB-GCPQ } \\
\text { nanoparticles }\end{array}$} & Mice CD-1 $(n=4)$ & $5 \mathrm{mg} / \mathrm{kg}$ & - & 4 & 0.308 & 0.985 & 1.364 & 1.119 & 1.608 & - & - & \multirow{2}{*}{ [15] } \\
\hline & Beagles $(n=3)$ & $4 \mathrm{mg} / \mathrm{kg}$ & - & 8 & 0.065 & - & - & - & - & - & - & \\
\hline
\end{tabular}


Table 3. Multiple dose oral pharmacokinetics animal studies with AmB. Key:-, data no available; ND, no detectable, below limit of quantification; Peceol (Self-emulsify ing drug delivery system formulation: SEDDS); DSPE/PEG2000 (iCo-009), distearoylphosphatidiylethanolamine-poly-(ethylene glycol) 2000; iCo 010, 60/40 (v/v) mono- and diglycerides with vitamin E-TPGS (D- $\alpha$-tocopheryl polyethylene glycol succinate); VL-mice, visceral leishmaniasis infected mice; BID, twice a day; GCPQ- N-palmitoyl-Nmethyl-N,N-dimethyl-N,N,N-trimethyl-6-O-glycol chitosan.

\begin{tabular}{|c|c|c|c|c|c|c|c|c|c|c|c|}
\hline \multirow{2}{*}{ Formulation } & \multirow{2}{*}{$\begin{array}{c}\text { Animal model } \\
\left(\mathrm{n}^{\circ} \text { animals }\right)\end{array}$} & \multirow{2}{*}{$\begin{array}{l}\text { Therapy } \\
\text { (duration) }\end{array}$} & \multirow{2}{*}{$\begin{array}{c}\begin{array}{c}\text { Collection of the } \\
\text { samples }\end{array} \\
\end{array}$} & \multirow{2}{*}{$\begin{array}{c}\begin{array}{c}\text { Conc. plasma } \\
(\mu \mathrm{g} / \mathrm{mL})\end{array} \\
\end{array}$} & \multicolumn{6}{|c|}{ AmB concentration in tissues $(\mu \mathrm{g} \mathrm{AmB} / \mathrm{g}$ tissue $)$} & \multirow{2}{*}{ Ref. } \\
\hline & & & & & Liver & Spleen & Kidney & Lung & Brain & Heart & \\
\hline AmB-Cochleates & $\begin{array}{l}\text { Mice C57BL16 } \\
\qquad(\mathrm{n}=3)\end{array}$ & $\begin{array}{c}10 \mathrm{mg} / \mathrm{kg} / \text { day } \\
\text { day })\end{array}$ & $\begin{array}{l}\text { Organs collected } 24 \mathrm{~h} \\
\text { post-administration }\end{array}$ & ND & 2.4 & 1.5 & 2.3 & 9.5 & 0.1 & 0.3 & {$[19]$} \\
\hline \multirow{4}{*}{$\begin{array}{l}\text { Peceol/DSPE/ } \\
\text { PEG }_{2000}-\text { AmB }\end{array}$} & Mice BALB/c (n=8) & $\begin{array}{c}2.5 \mathrm{mg} / \mathrm{kg} \text { BID } \\
(5 \text { day s) }\end{array}$ & \multirow{4}{*}{$\begin{array}{l}\text { Organs collected } 12 \mathrm{~h} \\
\text { post-administration }\end{array}$} & 0.166 & 0.714 & 0.329 & 0.112 & 0.589 & 0.082 & 0.160 & \multirow{4}{*}{ [22] } \\
\hline & Mice $B A L B / c(n=8)$ & $\begin{array}{c}5 \mathrm{mg} / \mathrm{kg} \text { BID } \\
\text { (5 days) }\end{array}$ & & 0.168 & 0.957 & 0.751 & 0.323 & 1.449 & 0.112 & 0.289 & \\
\hline & Mice BALB/c (n=8) & $\begin{array}{c}10 \mathrm{mg} / \mathrm{kg} \text { BID } \\
\text { (5 day s) }\end{array}$ & & 0.390 & 3.151 & 1.920 & 0.928 & 4.076 & 0.160 & 0.626 & \\
\hline & Mice BALB/c $(n=6)$ & $\begin{array}{c}20 \mathrm{mg} / \mathrm{kg} \text { BID } \\
\text { (5 days) }\end{array}$ & & 0.519 & 4.728 & 4.194 & 1.589 & 5.048 & 0.184 & 0.621 & \\
\hline \multirow{4}{*}{$\begin{array}{c}\text { Peceol/DS PE/ } \\
\text { PEG }_{2000}-\text { AmB }\end{array}$} & Mice BALB/c $(n=5)$ & $\begin{array}{c}10 \mathrm{mg} / \mathrm{kg} \text { BIB } \\
\text { (5 days) }\end{array}$ & \multirow{4}{*}{$\begin{array}{l}\text { Organs collected } 60 \mathrm{~h} \\
\text { post-administration }\end{array}$} & - & 0.328 & 0.152 & - & - & - & - & \multirow{4}{*}{ [24] } \\
\hline & $\begin{array}{l}\text { VL- Mice BALB/c } \\
(\mathrm{n}=6)\end{array}$ & $\begin{array}{c}10 \mathrm{mg} / \mathrm{kg} \text { BID } \\
5 \text { days })\end{array}$ & & - & 0.125 & 0.233 & - & - & - & - & \\
\hline & Mice BALB/c (n=5) & $\begin{array}{c}20 \mathrm{mg} / \mathrm{kg} \text { BID } \\
(5 \text { days })\end{array}$ & & - & 0.536 & 0.477 & - & - & - & - & \\
\hline & $\begin{array}{l}\text { VL- Mice BALB/c } \\
(\mathrm{n}=6)\end{array}$ & $\begin{array}{c}20 \mathrm{mg} / \mathrm{kg} \text { BID } \\
\text { (5 days) }\end{array}$ & & - & 0.171 & 0.428 & - & - & - & - & \\
\hline \multirow{4}{*}{ iCo-010 } & Mice BALB/c $(n=6)$ & $\begin{array}{c}2.5 \mathrm{mg} / \mathrm{kg} \text { BID (5 } \\
\text { day s) }\end{array}$ & \multirow{4}{*}{$\begin{array}{l}\text { Organs collected } 12 \mathrm{~h} \\
\text { post-administration }\end{array}$} & 0.172 & 0.446 & 0.342 & 0.495 & 0.408 & 0.059 & 0.084 & \multirow{4}{*}{ [29] } \\
\hline & Mice BALB/c (n=6) & $\begin{array}{c}5 \mathrm{mg} / \mathrm{kg} \text { BID } \\
\text { (5 days) }\end{array}$ & & 0.232 & 0.836 & 0.916 & 0.813 & 1.168 & 0.112 & 0.156 & \\
\hline & Mice BALB/c $(n=6)$ & $\begin{array}{c}10 \mathrm{mg} / \mathrm{kg} \text { BID } \\
\text { (5 day s) }\end{array}$ & & 0.418 & 2.543 & 1.407 & 2.268 & 2.014 & 0.157 & 0.338 & \\
\hline & Mice BALB/c $(n=7)$ & $\begin{array}{c}20 \mathrm{mg} / \mathrm{kg} \text { BID } \\
\text { (5 days) }\end{array}$ & & 0.538 & 3.494 & 1.939 & 3.685 & 3.179 & 0.169 & 0.366 & \\
\hline \multirow{2}{*}{$\begin{array}{l}\text { AmB-GCPQ } \\
\text { nanoparticles }\end{array}$} & $\begin{array}{l}\text { Mice CD-1 } \\
(\mathrm{n}=3)\end{array}$ & $\begin{array}{c}5 \mathrm{mg} / \mathrm{kg} / \text { day } \\
(5 \text { day })\end{array}$ & $\begin{array}{l}\text { Organs collected } 24 \mathrm{~h} \\
\text { post-administration }\end{array}$ & 0.229 & 0.892 & 1.716 & 1.405 & 1.548 & 0.139 & - & \multirow{2}{*}{ [15] } \\
\hline & $\begin{array}{l}\text { Mice CD-1 } \\
(\mathrm{n}=3)\end{array}$ & $\begin{array}{c}5 \mathrm{mg} / \mathrm{kg} \mathrm{BID} \\
\text { (5 days) }\end{array}$ & $\begin{array}{l}\text { Organs collected } 12 \mathrm{~h} \\
\text { post-administration }\end{array}$ & 0.462 & 6.281 & 7.884 & 3.346 & 7.456 & 0.280 & - & \\
\hline
\end{tabular}


Table 4. Oral efficacy studies with AmB against visceral leishmaniasis. Efficacy compared with non-treated controls. Key: -, data no available; ZP, zeta potential, p.i, post infection; f-CNTs, functionalized carbonnanotubes; iCo 010, 60/40 (v/v) mono- and diglycerides (Peceol/Gelucire 44/14) with vitamin E-TPGS (D- $\alpha$-tocopheryl polyethylene glycol succinate); BID, twice a day; QD, four times a day; GCPQ- N-palmitoyl-N-methyl-N, N-dimethyl-N,N,N-trimethyl-6-O-glycol chitosan, p.i, post infection.

\begin{tabular}{|c|c|c|c|c|c|c|c|c|}
\hline \multirow{2}{*}{$\begin{array}{l}\text { Formulation } \\
\text { composition }\end{array}$} & \multirow{2}{*}{$\begin{array}{l}\text { Formulations } \\
\text { characteristics }\end{array}$} & \multirow{2}{*}{$\begin{array}{c}\text { Animal } \\
\text { model }\end{array}$} & \multirow[t]{2}{*}{ Infection model } & \multirow{2}{*}{$\begin{array}{c}\mathbf{N}^{\circ} \text { of } \\
\text { animals }\end{array}$} & \multirow[t]{2}{*}{ Therapy } & \multicolumn{2}{|c|}{$\begin{array}{c}\text { Parasitemia load } \\
\text { reduction }(\%)\end{array}$} & \multirow[t]{2}{*}{ Reference } \\
\hline & & & & & & Liver & Spleen & \\
\hline $\begin{array}{c}\text { Nanosuspension } \\
0.4 \% \text { AmB }(\mathrm{w} / \mathrm{w}), \\
0.5 \% \text { Tween } 80(\mathrm{w} / \mathrm{w}), \\
0.25 \% \text { Pluronic F68 (w/w), } \\
0.05 \% \text { sodium cholate } \\
\text { (w/w) }\end{array}$ & $\begin{array}{c}\text { Size: } 528 \mathrm{~nm} \\
\text { ZP: }-38 \mathrm{mV} \\
\text { Stability: }>21 \text { days at } 20^{\circ}\end{array}$ & $\begin{array}{l}\mathrm{BALB} / \mathrm{c} \\
\text { mice }\end{array}$ & $\begin{array}{l}\text { IV infection with } 1 \times 10^{7} \mathrm{~L} . \\
\text { donovani amastigotes. } \\
\text { Treatment: } 7 \text { days p.i. } \\
\text { Sacrifice: } 14 \text { days p.i. }\end{array}$ & - & $5 \mathrm{mg} / \mathrm{kg}$ (4-5 days) & 28.6 & $1-0$ & {$[20]$} \\
\hline \multirow{4}{*}{ Lipid-based formulation } & \multirow{4}{*}{ - } & \multirow{4}{*}{$\begin{array}{l}\mathrm{BALB} / \mathrm{c} \\
\text { mice }\end{array}$} & \multirow{4}{*}{$\begin{array}{l}\text { IV infection with } 5 \times 10^{7} \mathrm{~L} \text {. } \\
\text { donovani promastigotes. } \\
\text { Treatment: } 7 \text { days p.i. } \\
\text { Sacrifice: } 14 \text { days p.i. }\end{array}$} & 4 & $2.5 \mathrm{mg} / \mathrm{kg}$ BID (5 days) & 64.7 & - & \multirow{4}{*}{ [33] } \\
\hline & & & & 4 & $5 \mathrm{mg} / \mathrm{kg}$ BID (5 days) & 96.4 & - & \\
\hline & & & & 5 & $10 \mathrm{mg} / \mathrm{kg}$ BID (5 days) & 99.5 & - & \\
\hline & & & & 5 & 20 mg/kg BID (5 days) & 99.8 & - & \\
\hline \multirow{4}{*}{ iCo -010} & \multirow{4}{*}{$\begin{array}{c}\text { Size } \approx 200 \mathrm{~nm} \\
\text { Stability: AmB > 75\% } \\
\text { over } 60 \text { days a } 30 \text { and } 43 \\
{ }^{\circ} \mathrm{C}\end{array}$} & \multirow{4}{*}{$\begin{array}{l}\mathrm{BALB} / \mathrm{c} \\
\text { mice }\end{array}$} & \multirow{4}{*}{$\begin{array}{l}\text { IV infection with } 5 \times 10^{7} \mathrm{~L} \text {. } \\
\text { donovani promastigotes. } \\
\text { Treatment: } 7 \text { days p.i. } \\
\text { Sacrifice: } 14 \text { days p.i. }\end{array}$} & 4 & $2.5 \mathrm{mg} / \mathrm{kg}$ BID (5 days) & 83 & - & \multirow{4}{*}[34]{} \\
\hline & & & & 4 & $5 \mathrm{mg} / \mathrm{kg}$ BID (5 days) & 98 & - & \\
\hline & & & & 4 & 10 mg/kg BID (5 days) & 99 & - & \\
\hline & & & & 4 & 20 mg/kg QD (5 days) & 96 & - & \\
\hline \multirow{3}{*}{ AmB attached to f-CNTs } & \multirow{3}{*}{-} & \multirow{3}{*}{$\begin{array}{l}\text { Golden } \\
\text { hamster }\end{array}$} & \multirow{3}{*}{$\begin{array}{l}\text { Intracardiac infection with } 1 \mathrm{x} \\
10^{8} \text { L. donovani promastigotes. } \\
\text { Treatment: } 30 \text { days p.i. } \\
\text { Sacrifice: } 37 \text { days p.i. }\end{array}$} & 8 & $5 \mathrm{mg} / \mathrm{kg} /$ day (5 days) & - & 90.2 & \multirow{3}{*}[21]{} \\
\hline & & & & 7 & 10 mg/kg/day (5 days) & - & 96.5 & \\
\hline & & & & 8 & $15 \mathrm{mg} / \mathrm{kg} /$ day (5 days) & - & 98.2 & \\
\hline \multirow{2}{*}{$\begin{array}{c}\text { AmB-GCPQ } \\
\text { nanoparticles }\end{array}$} & \multirow{2}{*}{$\begin{array}{c}\text { Size: } 216 \mathrm{~nm} \\
\mathrm{ZP}:+3 \mathrm{mV} \\
\text { Stability: } \mathrm{AmB}>95 \% \text { at } \\
4^{\circ} \mathrm{C}\end{array}$} & \multirow[t]{2}{*}{$\begin{array}{l}\mathrm{BALB} / \mathrm{c} \\
\text { mice }\end{array}$} & \multirow{2}{*}{$\begin{array}{l}\text { Intracardiac infection with } 1 \mathrm{x} \\
107 \text { L. infantum promastigotes } \\
\text { Treatment. } 24 \text { days p.i. } \\
\text { Sacrifice: } 31 \text { days p.i. }\end{array}$} & 8 & $5 \mathrm{mg} / \mathrm{kg} /$ day (5 days) & - & - & \multirow{2}{*}[15]{} \\
\hline & & & & 8 & $5 \mathrm{mg} / \mathrm{kg} /$ day (10 days) & 98.9 & 92.1 & \\
\hline
\end{tabular}


Table 5. Oral efficacy studies with AmB against apergillosis. Efficacy compared with non-treated controls. Key: -, data no available; CFU, colony forming units; p.i, potinfection; NSD, no significant differences ( $>0.05$ ) between treatment and control groups; DSPE/PE, distearoylphosphatidylethanolamine - polyethylenglycol, PLGA: polylactic-co-glycolic Acid; IP, intraperitoneally; SC, subcutaneously; BID, twice a day; GCPQ- N-palmitoyl-N-methyl-N,N-dimethyl-N,N,N-trimethyl-6-O-glycol chitosan, p.i, post infection; * values obtained 8 days p.i.

\begin{tabular}{|c|c|c|c|c|c|c|c|c|c|c|c|c|c|}
\hline \multirow{2}{*}{ Formulation } & \multirow{2}{*}{$\begin{array}{c}\text { Animal } \\
\text { model }\end{array}$} & \multirow[b]{2}{*}{ Infection model } & \multirow{2}{*}{$\begin{array}{c}\mathrm{N}^{\circ} \text { of } \\
\text { animals }\end{array}$} & \multirow{2}{*}{$\begin{array}{l}\text { Therapy } \\
\text { (duration) }\end{array}$} & \multicolumn{2}{|c|}{ \% of survival } & \multicolumn{6}{|c|}{ Aspergillus CFU reduction (\%) } & \multirow[b]{2}{*}{ Reference } \\
\hline & & & & & $\begin{array}{r}\text { After } 4 \\
\text { days p.i. }\end{array}$ & $\begin{array}{l}\text { After } 14 \\
\text { days p.i. }\end{array}$ & Liver & Spleen & Brain & Lungs & Heart & Kidneys & \\
\hline \multirow{2}{*}{$\begin{array}{l}\text { AmB- } \\
\text { cochleates }\end{array}$} & \multirow{2}{*}{$\begin{array}{l}\mathrm{BALB} / \mathrm{c} \\
\text { mice }\end{array}$} & \multirow{2}{*}{$\begin{array}{l}\text { Neutropenia with cyclophosphamide } \\
200 \mathrm{mg} / \mathrm{kg} \text { day }-3 \mathrm{p} \text {.i. IV infection with } \\
10^{6} \text { spores of A. fumigatus. Treatment } \\
\text { immediately after infection. }\end{array}$} & 10 & $\begin{array}{c}20 \mathrm{mg} / \mathrm{kg} / \mathrm{day} \\
(14 \text { days })\end{array}$ & 70 & 60 & - & - & - & - & - & - & \multirow{2}{*}{ [37] } \\
\hline & & & 10 & $\begin{array}{l}40 \mathrm{mg} / \mathrm{kg} / \text { day } \\
\text { (14 days })\end{array}$ & 90 & 70 & - & - & - & - & - & - & \\
\hline $\begin{array}{c}\text { AmB } \\
\text { incorporated } \\
\text { into Peceol }\end{array}$ & $\begin{array}{c}\text { Sprague } \\
\text {-Dawley } \\
\text { Rat }\end{array}$ & $\begin{array}{l}\text { IV injection with } 2.1-2.5 \times 10^{\prime} \mathrm{CFU} \text { of } \\
\text { A. fumigatus. Treatment: } 48 \mathrm{~h} \text { p.i. }\end{array}$ & 7 & $\begin{array}{l}50 \mathrm{mg} / \mathrm{kg} \\
(4 \text { days })\end{array}$ & - & - & NSD & 98 & 95 & NSD & NSD & NSD & [36] \\
\hline $\begin{array}{c}\text { Peceol/DSPE/ } \\
\text { PEG }_{2000}- \\
\text { AmB }\end{array}$ & $\begin{array}{l}\text { Sprague } \\
\text {-Dawley } \\
\text { Rat }\end{array}$ & $\begin{array}{l}\text { IV injection with } 2.9-3.45 \times 10^{7} \mathrm{CFU} \text { of } \\
\text { A. fumigatus. Treatment: } 48 \mathrm{~h} \text { p.i. } \\
\text { Sacrifice: day } 3\end{array}$ & 7 & $\begin{array}{l}10 \mathrm{mg} / \mathrm{kd} \text { BID } \\
\text { (2 days) }\end{array}$ & - & - & NSD & 90.1 & 79.2 & NSD & NSD & 87.9 & [35] \\
\hline \multirow{4}{*}{$\begin{array}{l}\text { AmB - PLGA } \\
\text { nanoparticles }\end{array}$} & \multirow{4}{*}{$\begin{array}{l}\mathrm{CD}-1 \\
\text { mice }\end{array}$} & \multirow{2}{*}{$\begin{array}{l}\text { Neutropenia with cyclophosphamide } \\
200 \mathrm{mg} / \mathrm{kg} \mathrm{IP}+\text { cortisone } 250 \mathrm{mg} / \mathrm{kg} \mathrm{SC} \text { : } \\
\text { day }-2 \text { and }+3 \text { p.i. Infection by } \\
\text { nebulization of } 8.1 \times 10^{8} \mathrm{CFU} \text { of A. } \\
\text { fumigatus spores } / \mathrm{ml} 1 \mathrm{~h} \text {. Treatment: } 5 \mathrm{~h} \\
\text { p.i. Sacrifice: } 101 \mathrm{~h} \text { p.i. }\end{array}$} & 6 & $5 \mathrm{mg} / \mathrm{kg}$ & - & - & - & - & - & 95.0 & - & - & \multirow{4}{*}[17]{} \\
\hline & & & 6 & $\begin{array}{c}5 \mathrm{mg} / \mathrm{kg} / \text { day } \\
\text { (4 days) }\end{array}$ & - & - & - & - & - & 99.7 & - & - & \\
\hline & & \multirow{2}{*}{$\begin{array}{l}\text { Neutropenia with cyclophosphamide } \\
200 \mathrm{mg} / \mathrm{kg} \text { IP day }-3 \text { p.i. IV infection } \\
\text { with } 8 \text { x } 10^{4} \text { CFU of A. fumigatus. } \\
\text { Treatment: } 5 \text { h p.i. Sacrifice: } 101 \text { h p.i. }\end{array}$} & 5 & $2 \mathrm{mg} / \mathrm{kg}$ & - & - & - & - & - & - & - & 78.1 & \\
\hline & & & 5 & $5 \mathrm{mg} / \mathrm{kg}$ & - & - & - & - & - & - & - & 98.0 & \\
\hline \multirow{3}{*}{$\begin{array}{c}\text { AmB-GCPQ } \\
\text { nanoparticles }\end{array}$} & \multirow{3}{*}{$\begin{array}{l}\text { OF-1 } \\
\text { mice }\end{array}$} & \multirow{3}{*}{$\begin{array}{l}\text { Neutropenia with cy clophosphamide } \\
200 \mathrm{mg} / \mathrm{kg} \text { IP and fluorouracil } 150 \\
\mathrm{mg} / \mathrm{kg} \mathrm{IV} \mathrm{at} \mathrm{day}-1 \mathrm{p} . \text {.i. IV infection } \\
\text { with } 1 \times 10^{4} \mathrm{CFU} \text { of } \text { A. fumigatus. } \\
\text { Treatment: } 24 \text { h p.i. Sacrifice: } 14 \text { days. }\end{array}$} & 10 & $\begin{array}{c}5 \mathrm{mg} / \mathrm{kg} \\
(10 \text { days }) \\
\end{array}$ & 100 & 25 & - & - & - & $60^{*}$ & - & $40^{*}$ & \multirow{3}{*}{ [15] } \\
\hline & & & 15 & $\begin{array}{l}7.5 \mathrm{mg} / \mathrm{kg} \\
(10 \text { days }) \\
\end{array}$ & 100 & 25 & - & - & - & $>95^{*}$ & - & $>95^{*}$ & \\
\hline & & & 15 & $\begin{array}{l}15 \mathrm{mg} / \mathrm{kg} \\
(10 \text { days })\end{array}$ & 100 & 20 & - & - & - & $>95^{*}$ & - & $>95^{*}$ & \\
\hline
\end{tabular}


Table 6. Oral efficacy studies with AmB against candidiasis. Efficacy compared with non-treated controls. Key: NSD, no significant differences (p>0.05) between treatment and control groups; -, data no available; DSPE/PEG2000 (iCo-009), distearoylphosphatidiylethanolamine-poly-(ethylene glycol) 2000; BID, twice a day. GCPQ- N-palmitoyl$\mathrm{N}$-methyl-N,N-dimethyl-N,N,N-trimethyl-6-O-glycol chitosan, p.i, post infection.

\begin{tabular}{|c|c|c|c|c|c|c|c|c|c|c|}
\hline \multirow{2}{*}{ Formulation } & \multirow{2}{*}{$\begin{array}{l}\text { Animal } \\
\text { model }\end{array}$} & \multirow{2}{*}{ Infection model } & \multirow{2}{*}{$\begin{array}{c}\mathrm{N}^{0} \text { of } \\
\text { animals }\end{array}$} & \multirow{2}{*}{ Therapy } & \multirow{2}{*}{$\begin{array}{c}\text { \% of } \\
\text { survival } \\
\text { After } 15 \\
\text { days p.i. }\end{array}$} & \multicolumn{4}{|c|}{ Candiadiasis CFU reduction $(\%)$} & \multirow{2}{*}{ Ref. } \\
\hline & & & & & & Lungs & Kidneys & Spleen & Liver & \\
\hline \multirow{2}{*}{$\begin{array}{c}\text { Peceol/DSPE/ } \\
\text { PEG 2000 - } \\
\text { AmB }\end{array}$} & \multirow{2}{*}{$\begin{array}{l}\text { Sprague- } \\
\text { Dawley } \\
\text { Rat }\end{array}$} & \multirow{2}{*}{$\begin{array}{l}\text { IV injection with 1-1.35 x } 10^{6} \\
\text { CFU of } C . \text { Albicans. } \\
\text { Treatment: } 48 \text { h p.i. } \\
\text { Sacrifice: day } 3 \\
\end{array}$} & 5 & $\begin{array}{c}5 \mathrm{mg} / \mathrm{kg} \text { BID } \\
\text { (2 days })\end{array}$ & - & NSD & 75 & - & - & \multirow{2}{*}{ [35] } \\
\hline & & & 7 & $\begin{array}{c}10 \mathrm{mg} / \mathrm{kg} \text { BID } \\
\text { (2 days) }\end{array}$ & - & NSD & 95 & - & - & \\
\hline \multirow{6}{*}{$\begin{array}{c}\text { AmB - } \\
\text { cochelates }\end{array}$} & \multirow{6}{*}{$\begin{array}{l}\mathrm{BALB} / \mathrm{c} \\
\text { mice }\end{array}$} & \multirow{6}{*}{$\begin{array}{l}\text { IV injection with } 10^{6} \\
\text { blastoconidia of } C \text {. Albicans. } \\
\text { Treatment: } 24 \text { h p.i. } \\
\text { Sacrifice: day } 17 \text { p.i. }\end{array}$} & 10 & $\begin{array}{c}0.5 \mathrm{mg} / \mathrm{kg} / \mathrm{day} \\
\text { (15 days) }\end{array}$ & 100 & NSD & NDS & - & - & \multirow{6}{*}{ [57] } \\
\hline & & & 10 & $\begin{array}{c}1 \mathrm{mg} / \mathrm{kg} / \text { day } \\
(15 \text { days })\end{array}$ & 100 & NSD & NDS & - & - & \\
\hline & & & 10 & $\begin{array}{c}2.5 \mathrm{mg} / \mathrm{kg} / \mathrm{day} \\
(15 \text { days })\end{array}$ & 100 & 100 & 99.97 & - & - & \\
\hline & & & 10 & $\begin{array}{c}5 \mathrm{mg} / \mathrm{kg} / \mathrm{day} \\
\text { (15 days) }\end{array}$ & 100 & 100 & 99.98 & - & - & \\
\hline & & & 10 & $\begin{array}{c}10 \mathrm{mg} / \mathrm{kg} / \mathrm{day} \\
(15 \text { days })\end{array}$ & 100 & 100 & 99.97 & - & - & \\
\hline & & & 10 & $\begin{array}{c}20 \mathrm{mg} / \mathrm{kg} / \mathrm{day} \\
(15 \text { days })\end{array}$ & 100 & 100 & 99.97 & - & - & \\
\hline $\begin{array}{c}\text { AmB-GCPQ } \\
\text { nanoparticles }\end{array}$ & $\begin{array}{l}\mathrm{BALB} / \mathrm{c} \\
\text { mice }\end{array}$ & $\begin{array}{c}\text { IV injection with } 1 \times 10^{6} \mathrm{CFU} \\
\text { of } C \text {. albicans. } \\
\text { Tretament: } 24 \mathrm{~h} \text { p.i. } \\
\text { Sacrifice: } 10 \text { days p.i. }\end{array}$ & 5 & $\begin{array}{c}5 \mathrm{mg} / \mathrm{kg} / \text { day } \\
(9 \text { days })\end{array}$ & 100 & - & NSD & 100 & 100 & [15] \\
\hline
\end{tabular}




\section{References}

[1] Oura M, Sternberg TH, Wright ET. A new antifungal antibiotic, amphotericin B. Antibiotics annual. 1955;3:566-73.

[2] Furtado TA. Clinical results in the treatment of American leishmaniasis with oral and intravenous amphotericin. Antibiotics annual. 1959;7:631-7.

[3] Serrano DR, Ballesteros MP, Schätzlein AG, Torrado JJ, Uchegbu IF. Amphotericin B Formulations - The Possibility of Generic Competition. Pharmaceutical Nanotechnology. 2013;1:250-8.

[4] Molefi M, Chofle AA, Molloy SF, KalluvyaS, Changalucha JM, Cainelli F, et al. AMBITION-cm: intermittent high dose AmBisome on a high dose fluconazol e backbone for cryptococcal meningitis induction therapy in sub-Saharan Africa: study protocol for a randomized controlled trial. Trials. 2015;16:276.

[5] Walsh TJ, Goodman JL, Pappas P, Bekersky I, Buell DN, Roden M, et al. Safety, tolerance, and pharmacokinetics of high-dose liposomal amphotericin $B$ (AmBisome) in patients infected with Aspergillus species and other filamentous fungi: maximum tolerated dose study. Antimicrobial agents and chemotherapy. 2001;45:3487-96.

[6] Ching MS, Raymond K, Bury RW, Mashford ML, Morgan DJ. Absorption of orally administered amphotericin B lozenges. British journal of clinical pharmacology. 1983;16:106-8. [7] Torrado JJ, Serrano DR, Uchegbu IF. The oral delivery of amphotericin B. Therapeutic delivery. 2013;4:9-12.

[8] Torrado JJ, Espada R, Ballesteros MP, Torrado-Santiago S. Amphotericin B formulations and drug targeting. Journal of pharmaceutical sciences. 2008;97:2405-25.

[9] Lipinski CA, Lombardo F, Dominy BW, Feeney PJ. Experimental and computational approaches to estimate solubility and permeability in drug discovery and development settings. Advanced drug delivery reviews. 2001;46:3-26.

[10] Ruiz HK, Serrano DR, Dea-Ayuela MA, Bilbao-Ramos PE, Bolas-Fernandez F, Torrado JJ, et al. New amphotericin B-gamma cyclodextrin formulation for topical use with synergistic activity against diverse fungal species and Leishmania spp. International journal of pharmaceutics. 2014;473:148-57.

[11] Serrano DR, Ruiz-Saldana HK, Molero G, Ballesteros MP, Torrado JJ. A novel formulation of solubilised amphotericin $B$ designed for ophthalmic use. International journal of pharmaceutics. 2012;437:80-2.

[12] Halde C, NewcomerVD, Wright ET, Sternberg TH. An evaluation of amphotericin B in vitro and in vivo in mice against Coccidioides immitis and Candida albicans, and preliminary observations concerning the administration of amphotericin B to man. The Journal of investigative dermatology. 1957;28:217-31; discussion, 31-2.

[13] Kravetz HM, Andriole VT, Huber MA, Utz JP. Oral administration of sol ubilized amphotericin B. The New England journal of medicine. 1961;265:183-4.

[14] Louria DB. Some aspects of the absorption, distribution, and excretion of amphotericin B in man. Antibiotic medicine \& clinical therapy. 1958;5:295-301.

[15] Serrano DR, Lalatsa A, Dea-Ayuela MA, Bilbao-Ramos PE, Garrett NL, Moger J, et al. Oral particle uptake and organ targeting drives the activity of amphotericin $B$ nanoparticles.

Molecular pharmaceutics. 2015;12:420-31.

[16] Patel PA, Patravale VB. AmbiOnp: solid lipid nanoparticles of amphotericin B for oral administration. Journal of biomedical nanotechnol ogy. 2011;7:632-9.

[17] Italia JL, Sharp A, Carter KC, Warn P, Kumar MN. Peroral amphotericin B polymer nanoparticles lead to comparable or superior in vivo antifungal activity to that of intravenous Ambisome(R) or Fungizone. PLoS One. 2011;6:e25744. 
[18] RisovicV, Boyd M, Choo E, Wasan KM. Effects of lipid-based oral formulations on plasma and tissue amphotericin $B$ concentrations and renal toxicity in male rats. Antimicrobial agents and chemotherapy. 2003;47:3339-42.

[19] Zarif L, Jin T, Segarral, Mannino R. Novel hydrogel isolated cochleate formulations, process of preparation and their use for the delivery of biologically relevant molecules. 2007. p. 27.

[20] Kayser O, Olbrich C, Yardley V, Kiderlen AF, Croft SL. Formulation of amphotericin B as nanosuspension for oral administration. International journal of pharmaceutics. 2003;254:735.

[21] Prajapati VK, Awasthi K, Yadav TP, Rai M, Srivastava ON, Sundar S. An oral formulation of amphotericin $B$ attached to functionalized carbon nanotubes is an effective treatment for experimental visceral leishmaniasis. The Journal of infectious diseases. 2012;205:333-6.

[22] Gershkovich P, Sivak O, Wasan EK, Magil AB, Owen D, Clement JG, et al. Biodistribution and tissue toxicity of amphotericin $B$ in mice following multiple dose administration of a novel oral lipid-based formulation (iCo-009). The Journal of antimicrobial chemotherapy. 2010;65:2610-3.

[23] Gershkovich P, Wasan EK, Lin M, Sivak O, Leon CG, Clement JG, et al. Pharmacokinetics and biodistribution of amphotericin $B$ in rats following oral administration in a novel lipidbased formulation. The Journal of antimicrobial chemotherapy. 2009;64:101-8.

[24] Gershkovich P, Wasan EK, Sivak O, Li R, Zhu X, Werbovetz KA, et al. Visceral leishmaniasis affects liver and spleen concentrations of amphotericin $B$ following administration to mice. The Journal of antimicrobial chemotherapy. 2010;65:535-7.

[25] Serrano DR, Hernandez L, Fleire L, Gonzalez-Alvarez I, Montoya A, Ballesteros MP, et al. Hemolytic and pharmacokinetic studies of liposomal and particulate amphotericin $B$ formulations. International journal of pharmaceutics. 2013;447:38-46.

[26] Seifert K, Escobar P, Croft SL. In vitro activity of anti-leishmanial drugs against Leishmania donovani is host cell dependent. The Journal of antimicrobial chemotherapy. 2010;65:508-11.

[27] Yardley V, Croft SL. A comparison of the activities of three amphotericin B lipid formulations against experimental visceral and cutaneous leishmaniasis. Int J Antimicrob Agents. 2000;13:243-8.

[28] Swinne D, Watelle M, Nolard N. In vitro activities of voriconazole, fluconazole, itraconazole and amphotericin B against non Candida albicans yeast isolates. Revista iberoamericana de micologia. 2005;22:24-8.

[29] Sivak O, Gershkovich P, Lin M, Wasan EK, Zhao J, Owen D, et al. Tropically stable novel oral lipid formulation of amphotericin B (iCo-010): biodistribution and toxicity in a mouse model. Lipids in health and disease. 2011;10:135.

[30] Osei-Twum JA, Wasan K. Does P-glycoprotein contribute to amphotericin B epithelial transport in Caco-2 cells? Drug development and industrial pharmacy. 2015;41:1130-6.

[31] Olivier M, Tanner CE. Susceptibilities of macrophage populations to infection in vitro by Leishmania donovani. Infection and immunity. 1987;55:467-71.

[32] Rolon M, Serrano DR, Lalatsa A, de Pablo E, Torrado JJ, Ballesteros MP, et al. Engineering Oral and Parenteral Amorphous Amphotericin B Formulations against Experimental Trypanosoma cruzi Infections. Molecular pharmaceutics. 2017.

[33] Wasan KM, Wasan EK, Gershkovich P, ZhuX, Tidwell RR, Werbovetz KA, et al. Highly effective oral amphotericin $B$ formulation against murine visceral leishmaniasis. The Journ al of infectious diseases. 2009;200:357-60.

[34] Wasan EK, Gershkovich P, Zhao J, Zhu X, Werbovetz K, Tidwell RR, et al. A novel tropically stable oral amphotericin $B$ formulation (iCo-010) exhibits efficacy against visceral Leishmaniasis in a murine model. PLoS neglected tropical diseases. 2010;4:e913.

[35] Wasan EK, Bartlett K, Gershkovich P, Sivak O, Banno B, Wong Z, et al. Development and characterization of oral lipid-based amphotericin B formulations with enhanced drug solubility, 
stability and antifungal activity in rats infected with Aspergillus fumigatus or Candida al bicans. International journal of pharmaceutics. 2009;372:76-84.

[36] Risovic V, Rosland M, Sivak O, Wasan KM, Bartlett K. Assessing the antifungal activity of a new oral lipid-based amphotericin B formulation following administration to rats infected with Aspergillus fumigatus. Drug development and industrial pharmacy. 2007;33:703-7.

[37] Delmas G, Park S, Chen ZW, Tan F, Kashiwazaki R, Zarif L, et al. Efficacy of orally delivered cochleates containing amphotericin $B$ in a murine model of aspergillosis. Antimicrobial agents and chemotherapy. 2002;46:2704-7.

[38] Auqarious Biotechnologies. Amphotericin Cochleates. Available in: http://www. aquariusbio.com/pipeline/. Accessed at: 16/07/2016.

[39] Clinical trials. CAMB/MAT2203 in Patients With Mucocutaneous Candidiasis (CAMB). Available at: https://clinicaltrials.gov/ct2/show/NCT02629419?term=cochleates\&rank=1. Accessed data: 15/07/2016.

[40] Zarif L, Graybill JR, Perlin D, Najvar L, Bocanegra R, Mannino RJ. Antifungal activity of amphotericin $B$ cochleates against Candida al bicans infection in a mouse model. Antimicrobial agents and chemotherapy. 2000;44:1463-9.

[41] Segarra I, Movshin DA, Zarif L. Pharmacokinetics and tissue distribution after intravenous administration of a single dose of amphotericin B cochleates, a new lipid-based delivery system. Journal of pharmaceutical sciences. 2002;91:1827-37.

[42] Sesana AM, Monti-Rocha R, Vinhas SA, Morais CG, Dietze R, Lemos EM. In vitro activity of amphotericin $B$ cochleates against Leishmania chagasi. Memorias do Instituto Oswaldo Cruz. 2011;106:251-3.

[43] Zarif L, Perlin D. Amphotericin B Nanocochleates : From Formulation to Oral Efficacy. Drug Delivery Technology. 2002;2:34-7.

[44] NM0147 METAmphizon. Nanomerics Ltd. "Making more of medicines". Available from: http://www.nanomerics.com/content/nm0147-metamphizon. Acessed data: 10/07/2016.

[45] ICo Therapeutics. amphotericin B oral formulation. Available from: http://www.icotherapeutics.com/pipeline/. Accessed date: 15/07/2016.

[46] Wasan KM, Sivak O, Bartlett K, Wasan EK, Gershkovich P. Novel oral amphotericin B formulation (iCo-010) remains highlyeffective against murine systemic candidiasis following exposure to tropical temperature. Drug development and industrial pharmacy. 2015;41:142530.

[47] Ibrahim F, Gershkovich P, Sivak O, Wasan EK, Wasan KM. Assessment of novel oral lipidbased formulations of amphotericin B using an in vitro lipolysis model. EJ Pharm Sci.

2012;46:323-8.

[48] Boyd M, Risovic V, Jull P, Choo E, Wasan KM. A stepwise surgical procedure to investigate the lymphatic transport of lipid-based oral drug formulations: Cannulation of the mesenteric and thoraciclymph ducts within the rat. J Pharmacol Toxicol Methods. 2004;49:115-20.

[49] Ali Khan A, MudassirJ, Mohtar N, Darwis Y. Advanced drug delivery to the lymphatic system: lipid-based nanoformulations. Int J Nanomedicine. 2013;8:2733-44.

[50] Ghosh S, Roy T. Nanoparticulate drug-delivery systems: Iymphatic uptake and its gastrointestinal applications. Journal of Applied Pharmaceutical Science 2014;4:123-30.

[51] Fratter A, Frare C, Uras G, Bonini M, Casari Bariani E, Ragazzo B, et al. New chitosan salt in gastro-resistant oral formulation could interfere with enteric bile salts emulsification of diet fats: preliminary laboratory observations and physiologic rationale. Journal of medicinal food. 2014;17:723-9.

[52] Trevaskis NL, Kaminskas LM, Porter CJ. From sewer to saviour - targeting the lymphatic system to promote drug exposure and activity. Nat Rev Drug Discov. 2015;14:781-803.

[53] Dereure J, Duong Thanh H, Lavabre-Bertrand T, Cartron G, Bastides F, Richard-Lenoble D, et al. Visceral leishmaniasis. Persistence of parasites in lymph nodes after clinical cure. The Journal of infection. 2003;47:77-81. 
[54] Zarif L, Tan F. Cochleates made with purified soy phosphatidulserine. US Patent 2003/0219473 A1. 2003.

[55] Robbie G, Wu TC, Chiou WL. Poor and unusually prolonged oral absorption of amphotericin B in rats. Pharmaceutical research. 1999;16:455-8.

[56] Italia JL, Yahya MM, Singh D, Ravi Kumar MN. Biodegra dable nanoparticles improve oral bioavailability of amphotericin $B$ and show reduced nephrotoxicity compared to intravenous Fungizone. Pharmaceutical research. 2009;26:1324-31.

[57] Santangelo R, Paderu P, Delmas G, Chen ZW, Mannino R, Zarif L, et al. Efficacy of oral cochleate-amphotericin $B$ in a mouse model of systemic candidiasis. Antimicrobial agents and chemotherapy. 2000;44:2356-60. 